\title{
The Impact of Conscious Awareness and Consumer Uniqueness on Consumer Ethnocentrism and Demographics Comparisons
}

\author{
Esra ÖZKAN PİR iD a \\ a Erzincan Binali Yıldırım University, Erzincan, Turkey. esraozkanpir@gmail.com
}

\begin{tabular}{ll}
\hline ARTICLE INFO & ABSTRACT \\
\hline $\begin{array}{l}\text { Keywords: } \\
\text { Conscious Awareness } \\
\text { Consumer Uniqueness } \\
\text { Consumer Ethnocentrism }\end{array}$ & $\begin{array}{l}\text { Purpose - This study aimed to interpret the differences stemming from the effect of demographic } \\
\text { variables by analysing the relationship between conscious awareness, consumer uniqueness, and } \\
\text { consumer ethnocentrism. } \\
\text { Design/methodology/approach - A survey has been carried across Turkey on consumers over 18 to } \\
\text { determine this relationship. The data obtained were interpreted through the SPSS package program. }\end{array}$ \\
$\begin{array}{l}\text { Received 17 August 2020 } \\
\text { Revised 8 January 2021 }\end{array}$ & $\begin{array}{l}\text { In the first part of the study, a literature review was conveyed to explain conscious awareness, } \\
\text { consumer uniqueness, and consumer ethnocentrism concepts. In the second part, conscious awareness } \\
\text { accepted 10 March 2021 } \\
\text { and the relationship between consumer uniqueness and consumer ethnocentrism are described. Thus, } \\
\text { regression, t-test and ANOVA analysis were conducted. } \\
\text { Article Classification: } \\
\text { Research Article }\end{array} \quad \begin{array}{l}\text { Findings - According to the analysis results, organizational consumer uniqueness positively affects } \\
\text { consumer ethnocentrism. Besides, differences have been achieved between demographic variables } \\
\text { and conscious awareness, consumer uniqueness, and consumer ethnocentrism. } \\
\text { Discussion - The effects of consumer uniqueness, ethnocentrism and similar phenomena on } \\
\text { consumption and purchasing habits are essential for marketing companies. In the analysis conducted } \\
\text { in this context, it was revealed that there is a positive relationship between consumer uniqueness and } \\
\text { consumer ethnocentrism, while no significant relationship was found between the conscious } \\
\text { awareness perceptions of consumers and consumer ethnocentrism. In addition, the study is thought } \\
\text { to contribute to both the literature and the sectoral field due to the limited number of studies on the } \\
\text { concept of consumer uniqueness in the literature and the analysis results. }\end{array}$
\end{tabular}

\section{Introduction}

Nowadays, increasingly competitive environment, globalization, and technological developments have led to several understanding changes in the marketing approach. Due to these changes, consumer importance has increased even more for producers. Consumer behaviour and the factors affecting consumer behaviour have gained significance for marketers. The new era marketing approach is based on consumer satisfaction by shifting the focus from the producer to the consumer. Thus, it is essential for marketers to determine consumer needs and to create suitable strategies. By changing and individualizing consumer behaviour, businesses have gone so far as to develop one-person markets with one-to-one marketing strategies. There have been many studies in the marketing literature concerning the factors affecting consumer behaviour and consumer needs. However, these studies are not sufficient to fully describe the endless human needs.

Among the policies adopted in many countries to overcome economic crises, there is a wide range of practices to increase consumption expenditures. These campaigns, which are carried out to stimulate domestic demand, also aim to consume domestic goods and support the domestic industry. However, ethnocentrism should not be seen only as an attitude towards foreign goods and services. Because while some people's ethnocentric tendencies are extremely strong, they can buy foreign products to meet their basic needs. There are individual differences in the way people view local practices according to their characteristics such as cultural openness, conservatism and ethnocentrism.

Awareness is when individuals evaluate their experiences instantly and judge their feelings, thoughts and knowledge as a result of this evaluation, positively or negatively, without adding comments. This thinking system forms the basis of conscious awareness. Individuals alert to what is happening around them are also

Özkan Pir, E. (2021). The Impact of Conscious Awareness and Consumer Uniqueness on Consumer Ethnocentrism and Demographics Comparisons, Journal of Business Research-Turk, 13 (1), 375-393. 
quite successful in their daily lives and managing to find solutions to the challenges they encounter logically and appropriately. Thereby, it is seen as a sign that they can make accurate decisions in their consumption habits and purchasing preferences.

Conscious awareness is a state that can be promoted regardless of individuals' mental state or demographic characteristics. It is an almost universal tool to increase the satisfaction and welfare of individuals (Dutt and Ninov, 2016: 85). Individuals with high conscious awareness are peaceful, happy and alert to what is happening around them. The individual knows how to define and evaluate the feelings and thoughts within (Kabat-Zinn and Hanh, 2009: 44). In studies on this subject, individuals with high conscious awareness use compatible coping strategies at a higher level (Weinstein et al., 2009), conscious awareness provides significant improvement in many areas that increase the quality of life of the individual (Flugel-Colle et al., 2009) correlates positively with well-being (Falkenström, 2010), conscious awareness is a predictor of positive emotional states (Brown and Ryan, 2003) are obtained. Based on the self-determination theory, it is possible to say that they successfully focused their consciously aware high attention on current events and experiences, thus successfully performing self-changing behaviours.

There are many studies in which consumers' attitudes towards foreign products are associated with their demographic characteristics, and interesting differences are striking among them. For example, Javalgi et al. (2005) stated that young consumers tend to consume domestic goods, while Schooler (1971) and Upadhyay and Singh (2006) found the opposite, that is, older consumers tend to consume domestic goods in another study. Although studies show different results according to different regions, they generally reveal that variables such as social class, education, income, travel frequency abroad, and the frequency of purchasing show inversely proportional changes with consumer ethnocentrism. However, with increasing age, the feeling of ethnocentrism increases and female consumers show a more ethnocentric profile (Shimp and Sharma,1987; Han, 1990; Mohammed et al. ,2000; Küçükemiroğlu, 1999; Wang, 1978; Good and Huddleston, 1995). Accordingly, older, low-income, low-education female consumers can be expected to be in the most ethnocentric group. According to Demir and Tansuhaj (2011), young people who are more influenced by mass communication and media are more likely to the attraction of global brands.

In other studies, consumer ethnocentrism is predicted to be in close relationship (Kaynak and Kara, 2002), culture, openness to change, conservatism, patriotism, nationalism, collectivism (Javalgi et al., 2005), sense of social acceptance (Conrad et al. , 1997), helping model (Granzin and Painter, 2001), tendency to prefer local products, product categories (Balabanis and Diamantopoulos, 2004), political events (Julie and Albaum, 2002), economic development levels of countries (Reardon et al. ., 2005), and demographic characteristics (Good and Huddleston, 1995). The measurement of consumer ethnocentrism levels of countries and their comparison are some of the studies conducted in the studies.

According to the sample groups in the studies focusing on ethnocentrism, it has been determined that Turkish consumers generally tend to moderate consumer ethnocentrism (Armağan and Gürsoy, 2011; İşler, 2013; Asil and Kaya, 2013; Uyar and Dursun, 2015; Toksarı and Senir, 2015; Tuncer and Gökşen , 2016). In this respect, it can be mentioned that the ethnocentric tendencies of Turkish consumers can be an effective variable in perception and preference of brands in terms of domestic and foreign origin characteristics. Ethnocentrism is mostly associated with purchasing decision styles and brand preference in Turkish sources, so the study conducted reveals the effect of conscious awareness and consumer uniqueness variables on ethnocentrism, and a different perspective has been developed sectorally.

Although the concept of ethnocentrism is new in international marketing literature, it is essential since it helps the consumer to comprehend the preference between domestic and foreign brands. It is possible to develop new perspectives on consumers' understanding of production and marketing by researching ethnocentrism and individual values.

With this research, new information that should be taken into consideration for managers and practitioners working in the field of marketing has been reached. Undoubtedly, the first requirement for businesses to enter a new market is to know and define the consumer. It is of great importance to collect "prior information" in determining the targets of the business for these markets. Part of this preliminary information is the ethnocentric attitudes of consumers and guiding factors for businesses that will operate in markets.Examining 
these effects before production and marketing allow determination of product targets that will fully meet the demands and needs of consumers and enable companies to gain an advantage over their competitors.It has been concluded that there are quite a few studies examining consumer uniqueness and conscious awareness in the literature reviews, existing studies often focus on consumer ethnocentrism, and no research has been conducted to determine the relationship between conscious awareness, consumer uniqueness, and consumer ethnocentrism. For these reasons, this study has been carried out. Our research sample was created from consumers over the age of 18 in our country, and the relationship between the conscious awareness of consumers and consumer uniqueness with consumer ethnocentrism was explained with the survey method.

The primary purpose of this research is to investigate the relationship between conscious awareness, consumer uniqueness, and consumer ethnocentrism, interpreting the differences that arise with the effect of demographic variables. The study consists of two parts. The first part consists of the theoretical background and literature review related to the research. The second part covers the research methodology and findings.

\section{Conceptual Framework}

\section{Conscious Awareness:}

Conscious Awareness is the art of living consciously by simply not judging, accepting, and focusing only on what is happening presently (Kabat-Zinn 2003; Brown and Ryan, 2003: Özyeşil et al. 2011; Y1kılmaz and Demir 2015; Lan et al. 2018). Conscious awareness allows the individual to analyse better both the events around him and the reasons for his reactions to these events. The thinking technique that covers this approach makes it easier to solve problems when confronted with a dilemma and increases creativity (Steele, 2008: 14). Siegel (2009) defined conscious awareness as moving life away from automaticity, being sensitive to what occurs in daily life and viewing from a different perspective. Brown and Ryan (2003) state that conscious awareness includes attention and awareness to all kinds of internal and external experiences happening at the moment.

Conscious awareness is the preference of an individual to think openly on negative emotions as soon as they arise, without trying to change or suppress, avoiding them, without judging oneself (Kirkpatrick, 2005: 12). With conscious awareness, individuals can focus and control their negative and disturbing features and circumstances while trying to discover and notice their positive aspects (Tırışkan et al. 2015; Crane et al. 2017).

Studies demonstrate that mindfulness-based interventions cause an average increase in the level of conscious awareness disposition (Shapiro et al.2008). Carmody et al. (2008) observed an increase in both trait awareness scores and state awareness scores of individuals according to the evaluations done before and after the conscious awareness-based stress reduction program. Studies on stress constitute a significant part of the studies investigating the effect of mindfulness on physiology (Good et al., 2016: 121). These studies generally study the relationship between physiological responses to stress stimuli and the conscious awareness feature and the effect of mindful awareness-based training (Küçük, 2019: 42).

According to the studies conducted, individuals with a high level of conscious awareness practice the strategies of coping harmonizingly and overcoming stressful experiences more (Weinstein et al. 2009). It is comprehended that mindfulness and well-being (Falkenström, 2010) and psychological adjustment are positively correlated (Lykins and Baer, 2009), and conscious awareness predicts self-regulation behaviour and positive emotional states (Brown and Ryan, 2003). It reveals that people with high conscious awareness also have high cognitive flexibility abilities (Moore and Malinowski, 2009: 179). Hodgins and Knee (2002) state that individuals with developed conscious awareness can use their awareness skills before automatically responding to feedback from their environment.

When the subject is considered from businesses sense, businesses that increase the level of conscious awareness of their personnel provide a stronger competitive advantage, create a consumer community loyal to the brand and offer a meaningful experience to the consumer (Van Gordon et al.2014: 135). Studies have shown that as a result of increasing the level of conscious awareness in individuals whose depression, anxiety, and mental health have been severely damaged, their health and quality of life improves (Laurie and Blandford, 2016: 2). 
The effect of conscious awareness on emotions is relevant to the degree of reaction and emotion to feel. Studies prove that people with high cognitive awareness, who encounter negative stimuli and experience negative emotions such as fear and anger, are less affected by these situations (Creswell et al. 2007: 562).

Conscious awareness causes a decrease, in particular, stress, anxiety and negative emotions (Weinstein et al. 2009; Shapiro, et al. 2011; Remmers, et al. 2016). Many referring studies show that mindfulness is positively associated with performance (Dane and Brummel, 2014; Reb et al. 2014; Shonin, et al. 2014). Allen and Kiburz (2012) state that there is a high positive relationship between conscious awareness and work-family balance.

\section{Consumer Uniqueness:}

The need for uniqueness is gathered in a set of unique needs such as commitment, power and hunger for success (Solomon, 2017: 178-179). The desire, strength or intensity of unique consumer products is a goaloriented situation that differs among individuals. Individual variances in the power of this desire are due to many reasons. Three of these reasons can be listed as "Desire for Status" (Cassidy and Lynn, 1989), "Materialism" (Belk, 1985) and "Need for Difference" (Snyder and Fromkin, 1980). The need for uniqueness is gathered in a set of unique needs such as commitment, power and hunger for success (Solomon, 2017: 178179).

Consumers' need to be unique is described as the ability to pursue differences compared to others through the acquisition, use and disposal of consumer goods to develop and increase self-respect and social image (Tian et al., 2001: 52).Consumers get and exhibit products that they perceive as valuable and marginal to feel different from other people, and thus may want to emphasize their uniqueness (Tian et al. 2001).

One alternative to meet people's needs for uniqueness is to acquire and own unique consumer products (Brock, 1968; Fromkin, 1970; Snyder and Fromkin, 1980; Snyder, 1992). Studies have suggested that the need for uniqueness is an essential source of demand for such products (Lynn, 1991). It has been demonstrated that the need for uniqueness of the consumer is mediated by consumer innovativeness and exploratory behaviour tendencies (Paşalığlu and Cengiz 2019: 43).Rajamma et al., (2010) comparatively analysed the effect of uniqueness and ethnocentric needs of consumers on generation $Y$ retail behaviours on American and Taiwanese consumers and found that the unique needs of consumers positively affect retail sales behaviours.

\section{Consumer Ethnocentrism:}

Ethnocentrism is the understanding of keeping formation, culture, belief and lifestyle superior to the lifestyle of other societies (Torlak and Özçelik, 2011: 366).

The concept of "consumer ethnocentrism", which is the dimension of ethnocentrism in consumer behaviour, was first adopted by Shimp in 1984. Shimp (1984) described the relationship within ethnocentrism and consumers' perceptions and attitudes of this concept as "consumer ethnocentrism". According to consumer ethnocentrism, due to the economic and moral reasons, consumers perceive their own country's products better quality and find it more appropriate to purchase these products (Shimp, 1984).

Consumers think that by consuming or purchasing the products of their own countries, they fulfill the duty of citizenship and show their loyalty to their country (Rybina et al., 2010: 97).

Ethnocentric consumers believe that outward purchasing harms the domestic and national economy. Although import is inevitable in international trade, for ethnocentric consumers, antipathy towards this trade means hostility towards the country (Jimenez and San Martin, 2010: 34-45).

Consumer Ethnocentrism constitutes purchaser opinion on consuming foreign goods. According to ethnocentrism, consumption of imported goods is unacceptable. Imported products are irrelevant for consumers with high ethnocentric tendencies. On the other hand, consumers with low ethnocentric tendency argue that the convenience offered to them by imported goods is too much and they should be used if they have advantages in price or quality when compared to the products of the country (Kaynak and Kara, 2001).Consumer ethnocentrism has been the subject of many studies since it found its way in the marketing literature. Researchers have studied various points, which factors affect this issue and what effects it causes. Studies have revealed that consumer ethnocentrism affects consumer behaviour positively or negatively. It is possible to consider the effects of consumer ethnocentrism from two aspects. The first is the factors influencing 
consumer ethnocentrism, and the second is the factors affecting the level of consumers' ethnocentric tendencies (Cömert, 2019: 26).

Although the studies carried provide collected data in various regions, it has been concluded that variables such as social class, income, education, and frequency of travel abroad vary inversely with customer ethnocentrism. Besides, as the age of the customer increases, the feeling of ethnocentrism increases and female customers create a more ethnocentric profile (Yousif, 2019: 65).In various countries, without specifying any sector (Good and Huddleston, 1995; Witkowski, 1998; Vida and Fairhurst, 1999; Kwak et al., 2006; Eryiğit and Kavak, 2011) and by specifying different sectors (Balabanis and Diamantopoulos, 2004; Yapraklı and Keser , 2013), it was determined that consumer ethnocentrism is measured intensely. Consumer ethnocentrism is an inevitable phenomenon that confronts the developed world. In some studies, it has been observed that the consumers of developed countries are in high demand for foreign goods (Papadopoulos et al., 1989; Mohamad et al., 2000), while others have found the opposite. For example, Varma (1998), in his study on Indian consumers, found that they showed very high demand for foreign goods and listed the reasons for this as the search for status symbols, inferiority complex, increase in consumer income, change in expectations and cultural openness of consumers to brands. In some cases, product characteristics can influence product preferences more strongly than ethnocentrism. Herche (1992) concluded that consumer ethnocentrism will have different effects for different product groups. Studies carried out in later years support this result. Uzkurt and Özmen (2004) also observed a high ethnocentric trend in Turkish consumers in their study, but found that there was no significant difference between high and low ethnocentric consumers in terms of price. Some socio-demographic characteristics are also considered to be the precursors of consumer ethnocentrism. In the study conducted by Okechuku and Onyemah (1999) with Nigerian consumers, it was revealed that the brands originating from developed countries are generally perceived as higher quality especially in luxury products (Piron, 2002). Balabanis and Diamantopoulos (2004) revealed that while consumption of domestic goods is high in consumption goods in Russia, this tendency is not found in durable consumption goods. Evanschitzky et al. (2008) found that there is a strong domestic product trend in the German market, but this trend differs according to product groups. These results confirm that the ethnocentrism levels of consumers vary according to product groups.

Evanschitzky et al. (2008) found in their study that there is a strong domestic country orientation in the German market. According to Okechuku (1994); consumers first buy products produced in their own country. However, if domestic products are not sufficient in terms of various features, then consumers intend to buy the products of countries that have good commercial relations with their countries. In another study, it was concluded that the patriotism of consumers plays an important role in their preference of domestic products over foreign products (Vasellaet al., 2010). According to Roth and Romeo (1992), the factors affecting the domestic and foreign product purchasing behaviour of consumers were shown as product class, information about the country of origin of the product, patriotism. The higher the consumers' ethnocentric tendency, the lower the intention to purchase foreign products and the higher the intention to purchase domestic products (Klein et al., 1998; Cutura, 2006; Kavak and Gümüşlüoğlu 2007; Evanschitzky et al., 2008).In a study, the intensity of personal values and country of origin influence was higher in Brazilian 29 and under age groups. Consequently, young consumers prefer foreign brands and products more than the elderly, and they are more open and accepting (Küçükaydın, 2012). In the study conducted to measure the influence of the country of origin effect on specific and convenience product groups, it was decided that the country of origin has an impact on the purchasing demands of customers for qualified goods. Besides, the country of origin effect could not be determined on the convenience product group (Yousif, 2019: 64).Consumers with a high ethnocentric tendency do not tolerate using imported goods and perceive the behaviour as a citizenship task for their country. According to researches, it is observed that there are more ethnocentric tendencies in developed countries. Still, also, the use of foreign products for the consumers of developing countries may be a reason for preference since it is a status determiner (Ünal, 2019: 40).

\section{Method}

\section{Research Model}

Basic independent variables of the research are Conscious awareness and Consumer uniqueness The dependent variable is consumer ethnocentrism. 
The research model is shown in Figure 1.

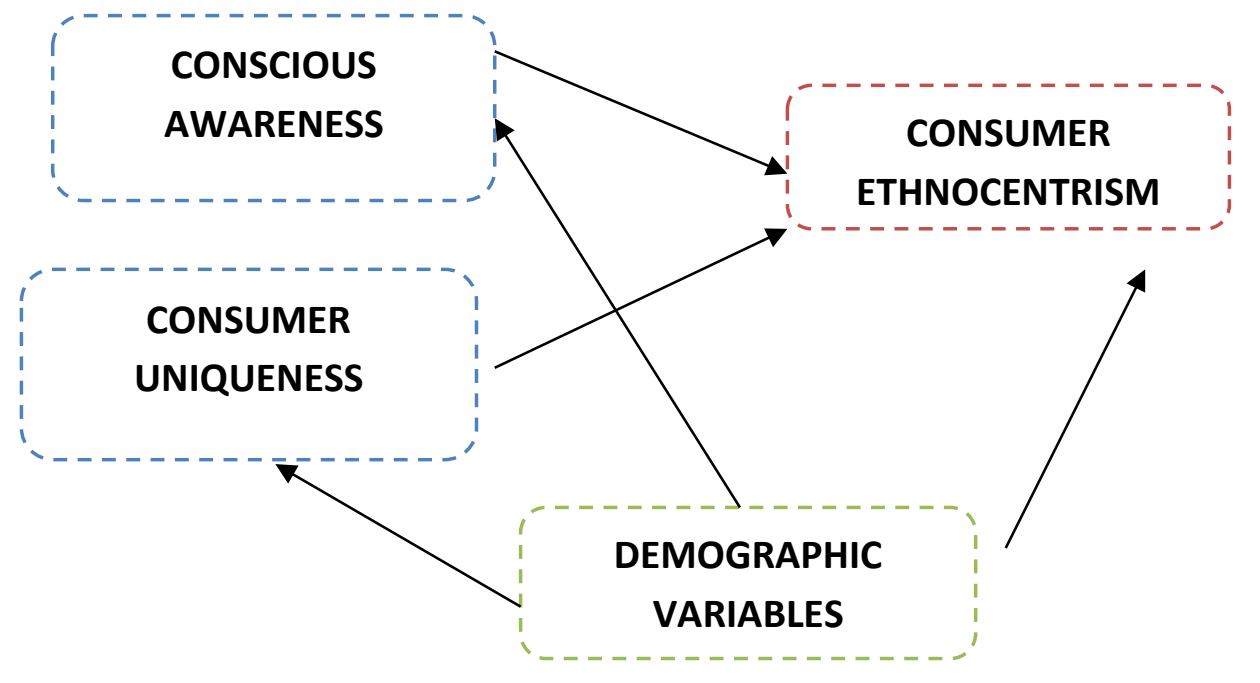

Figure 1: The Research Model

The research hypotheses are as follows;

H1: Conscious awareness has a statistically significant effect on consumer ethnocentrism.

H2: Consumer uniqueness has a statistically significant effect on consumer ethnocentrism.

H3: Gender makes a difference in variables.

H3a: Gender variable creates a significant difference in conscious awareness.

$\mathrm{H} 3 \mathrm{~b}$ : Gender variable creates a significant difference in consumer uniqueness.

H3c: Gender variable makes a significant difference on consumer ethnocentrism.

H4: Marital status makes a difference in variables.

H4a: Marital status variable makes a significant difference in conscious awareness.

H4b: Marital status variable creates a significant difference in consumer uniqueness.

H4c: Marital status variable makes a significant difference on consumer ethnocentrism.

H5: Age makes a difference in variables.

H5a: Age variable makes a significant difference in conscious awareness.

H5b: Age variable makes a significant difference in consumer uniqueness.

H5c: Age variable makes a significant difference on consumer ethnocentrism.

H6: Education makes a difference in variables.

H6a: Education variable creates a significant difference in conscious awareness.

H6b: Education variable makes a significant difference in consumer uniqueness.

H6c: Education variable makes a significant difference on consumer ethnocentrism.

H7: Income makes a difference in variables.

H7a: The income variable creates a significant difference in conscious awareness.

H7b: The income variable creates a significant difference in consumer uniqueness.

H7c: The income variable makes a significant difference on the consumer ethnocentrism. 


\section{Research Objective}

The research aims to reveal the effect of consumers' conscious awareness and consumer uniqueness perceptions on consumer ethnocentrism. Besides, it is another goal to define whether demographic variables make a significant difference in conscious awareness, consumer uniqueness and consumer ethnocentrism.

\section{Research Sample and Data Collection Method}

In the study, the convenience sampling method was preferred as the sampling method. The research population is composed of consumers aged 18 and over across Turkey. The applied questionnaire was created online. From the surveys sent to consumers in different parts of Turkey between 11-24 November 2019, 421 valid surveys were included in the study. The respondents were informed that the study would be used for a scientific purpose, and the volunteers were expected to respond to the questionnaire to obtain the required data.

\section{The Scales Used in the Research}

The first part of the questionnaire includes questions about obtaining demographic information. Consumers were questioned on gender, marital status, age, education level, income, marital status and occupation to get demographic information. In the second part, there are scales for conscious awareness (15 questions), consumer uniqueness (12 questions) and consumer ethnocentrism (17 questions), respectively. The scales used are arranged in a 5-point Likert. There are no reverse-coded items in the scales. There are 49 questions in the questionnaire form.

Conscious awareness scale was developed by Özyeşil et al. (2011). It consists of 15 items.

In the scale of consumer uniqueness, Paşalığlu (2018) 's master thesis study titled "The effect of lifestyle, consumer innovativeness and consumer uniqueness on the intention to buy electric vehicles" was used. Consumer uniqueness consists of 17 expressions. For the consumer uniqueness scale, five expressions such as "Yes" and "No", which are "supplementary statements", were removed from the analysis, and the scale became 12 items.

There are 17 questions adapted to the Consumer Ethnocentrism Scale. The scale developed by Sharma et al. $(1987 ; 1995)$ was used to measure consumer ethnocentrism.

\section{Findings}

In this part of the study, socio-demographic variables of the participants were subjected to percentage and frequency analysis. Correlation and regression analysis was conducted to determine the relationships between conscious awareness, consumer uniqueness and consumer ethnocentrism. Differences in demographic variables were tried to be determined by t-test and ANOVA. The data obtained have a normal distribution. SPSS package software was used to analyze and interpret the data set.

Cronbach's Alpha value shows the reliability level of the questions under the factor. The scale is considered to be reliable when the Cronbach's Alpha value is 0.70 and above. However, if there are few questions, this limit can be accepted as 0.60 and above. The reliability analysis results of the scales used in the research are given in Table 1.

Table 1: Reliability Analysis of Scales Used in the Study

\begin{tabular}{|l|l|l|l|}
\hline No & Lower Dimension & Item & Cronbach's Alpha \\
\hline 1 & Mindful Attention Awareness Scale & 15 & .904 \\
\hline 2 & Consumer uniqueness scale & 12 & .919 \\
\hline 3 & Consumer ethnocentrism scale & 17 & .944 \\
\hline
\end{tabular}

The Cronbach's alpha value of the conscious awareness scale is 0.904 . The Cronbach's alpha value of the consumer uniqueness scale is 0.919 . The Cronbach's alpha value of the consumer ethnocentrism scale is 0.944 . Cronbach alpha values resulting in this way suggests that the scales provide a reliable measurement.

The socio-demographic information of the employees participating in the study is given in Table 2: 
E. Özkan Pir 13/1 (2021) 375-393

Table 2: Distribution of Demographic Variables

\begin{tabular}{|l|l|c|c|}
\hline \multicolumn{2}{|l|}{} & Frequence & Per cent N\% \\
\hline 1- Your Gender & Female & 241 & 57.2 \\
\cline { 2 - 4 } & male & 180 & 42.8 \\
\hline \multirow{3}{*}{ 2. Marital Status. } & Single & 256 & 60.8 \\
\cline { 2 - 4 } & Married & 165 & 39.2 \\
\hline \multirow{5}{*}{ 4. Education } & $18-25$ & 178 & 42.3 \\
\cline { 2 - 4 } & $26-35$ & 130 & 30.9 \\
\cline { 2 - 4 } & $36-45$ & 81 & 19.2 \\
\cline { 2 - 4 } & 46 and above & 32 & 7.6 \\
\hline \multirow{5}{*}{5. Income Status } & high school & 72 & 17.1 \\
\cline { 2 - 4 } & Associate Degree & 101 & 24.0 \\
\cline { 2 - 4 } & Undergraduate degree & 172 & 40.9 \\
\cline { 2 - 4 } & Graduate & 76 & 18.1 \\
\hline & Less than 2,500 TL & 79 & 18.8 \\
\cline { 2 - 4 } & 2500-5000 & 71 & 16.9 \\
\cline { 2 - 4 } & 5001-7500 & 41 & 10.5 \\
\cline { 2 - 4 } & Higher than 7500 TL & 89 & 20.4 \\
\cline { 2 - 4 } & I do not have any regular income. & & \\
\hline
\end{tabular}

$57.2 \%$ of the consumers participating in the survey are female $(\mathrm{n}=241)$ and $42.8 \%$ are male $(\mathrm{n}=180) ; 60.8 \%$ are single $(n=256), 39.2 \%$ are married $(n=165) .42 .9 \%$ of the consumers surveyed were in the $18-25$ age range $(n$ $=178), 30.9 \%$ in the $26-35$ age range $(n=130), 19.2 \%$ in the $36-45$ age range $(n=81)$ and $7.6 \%$ were 46 years old and above $(n=72)$. Considering the educational status, $17.1 \%$ were high school graduates $(n=72), 24 \%$ were associate degree $(n=101), 40.9 \%$ were undergraduate $(n=172)$ and $18.1 \%$ were undergraduate graduates $(n=$ 76). $18.8 \%$ of the consumers have an income less than $2500 \mathrm{TL}(\mathrm{n}=79), 33.5 \%$ between $2500-5000 \mathrm{TL}(\mathrm{n}=141)$, $16.9 \%$ between $5001-7500(n=71), 10.5 \%$ of them have an income of $7500 \mathrm{TL}(\mathrm{n}=44)$ and $20.4 \%$ of them do not have a regular income.

Table 3 shows the regression analysis between awareness, consumer uniqueness, and consumer ethnocentrism.

Table 3. Regression Analysis Results

\begin{tabular}{|l|l|l|l|l|l|}
\hline \multirow{2}{*}{ Model } & \multicolumn{5}{l}{ Consumer ethnocentrism } \\
\cline { 2 - 6 } & $\mathrm{B}$ & Standard Error & $\mathrm{B}$ & $\mathrm{t}$ & $\mathrm{p}$ \\
\hline Conscious Awareness & 0.075 & 0.070 & 0.060 & 1.073 & 0.284 \\
\hline Consumer uniqueness & 0.292 & 0.079 & 0.209 & 3.719 & 0.000 \\
\hline & $\mathrm{R}=0.247$ & $\mathrm{R}^{2}=0.091$ & Durbin-Watson $=1.701$ & $\mathrm{~F}=13.571$ & $\mathrm{p}=0.000$ \\
\hline
\end{tabular}

According to the results, the multiple regression model between conscious awareness, consumer uniqueness, and consumer ethnocentrism was significant $(\mathrm{F}=13.571 ; \mathrm{p}<0.000)$. When the variables are examined, while conscious awareness does not have a significant effect on consumer ethnocentrism ( $p>0.000)$, consumer uniqueness has a significant effect on consumer ethnocentrism $(p<0.000)$. As a result of the findings, while H1 is rejected, $\mathrm{H} 2$ is accepted.

Table 4 shows the results of the t-test showing that the gender variable does not create a significant difference in the dependent and independent variables. 
Table 4. T-Test Results on Consumers' Gender and Conscious Awareness, Consumer Uniqueness, and Consumer Ethnocentrism

\begin{tabular}{|l|l|l|l|l|l|}
\hline Variable & Gender & $\mathbf{N}$ & $\mathbf{X}$ & $\mathbf{T}$ & Sig. (p) \\
\hline \multirow{2}{*}{ Conscious Awareness } & Female & 241 & 38.8216 & -5.590 & 0.000 \\
\cline { 2 - 5 } & Male & 180 & 45.4333 & & \\
\hline \multirow{2}{*}{ Consumer uniqueness } & Female & 241 & 32.4813 & -1.617 & 0.107 \\
\cline { 2 - 4 } & Male & 180 & 34.2500 & & \\
\hline \multirow{2}{*}{ Consumer ethnocentrism } & Female & 241 & 58.1992 & \multirow{2}{*}{1.277} & \multirow{2}{*}{0.202} \\
\cline { 2 - 4 } & Male & 180 & 56.2444 & & \\
\hline
\end{tabular}

Table 4 shows the results of the t-test regarding the participants' gender, conscious awareness, consumer uniqueness and consumer ethnocentrism. When these results are examined, it can be mentioned that there is a significant relationship between gender and conscious awareness at $95 \%$ confidence level $(\mathrm{p}<0.05)$. According to the averages, conscious awareness of male consumers is higher than female consumers. There is no significant difference between consumer uniqueness and consumer ethnocentrism and gender.

Table 5. T-Test Results on Consumers' Marital Status and Conscious Awareness, Consumer Uniqueness, and Consumer Ethnocentrism

\begin{tabular}{|l|l|l|l|l|l|}
\hline Variable & Marital & $\mathbf{N}$ & $\overline{\mathbf{X}}$ & $\mathbf{T}$ & Sig. (p) \\
& Status & & & & \\
\hline \multirow{2}{*}{ Conscious Awareness } & Single & 256 & 41.3320 & -0.185 & 0.516 \\
\cline { 2 - 5 } & Married & 165 & 42.1394 & & \\
\hline \multirow{2}{*}{ Consumer uniqueness } & Single & 256 & 34.1563 & 2.119 & 0.035 \\
\cline { 2 - 4 } & Married & 165 & 31.8121 & & \\
\hline \multirow{2}{*}{ Consumer ethnocentrism } & Single & 256 & 58.9766 & 2.672 & 0.008 \\
\cline { 2 - 4 } & Married & 165 & 54.8606 & & \\
\hline
\end{tabular}

Table 5 shows the t-test results regarding the marital status of consumers, conscious awareness, consumer uniqueness and consumer ethnocentrism. When these results are examined; it can be mentioned that there is a significant relationship between marital status and consumer uniqueness and consumer ethnocentrism at $95 \%$ confidence level $(\mathrm{p}<0.05)$. According to averages, single individuals have higher consumer uniqueness and consumer ethnocentrism than married consumers. There is no significant difference between conscious awareness and marital status.

Table 6. ANOVA Results on Consumers' Ages and Conscious Awareness, Consumer Uniqueness, and Consumer Ethnocentrism

\begin{tabular}{|l|l|l|l|l|}
\hline Variable & Age & $\begin{array}{l}\text { Mean } \\
\mathbf{( \mathbf { X } )}\end{array}$ & F Value & Sig. (p) \\
\hline Conscious Awareness & $18-25$ & 39.5730 & & \\
& $26-35$ & 41.7077 & 4.282 & 0.005 \\
& $36-45$ & 45.0741 & & \\
& 46 and above & 44.2813 & & \\
\hline Consumer uniqueness & $18-25$ & 34.2584 & & \\
& $26-35$ & 31.4385 & 1.719 & 0.162 \\
& $36-45$ & 33.8272 & & \\
\hline Consumer ethnocentrism & 46 and above & 33.3750 & & \\
& $18-25$ & 60.9831 & & \\
& $26-35$ & 55.9385 & 7.511 & \\
& $36-45$ & 51.6914 & & \\
\hline
\end{tabular}


Table 6 shows the results of ANOVA analysis concerning the ages of consumers and conscious awareness, consumer uniqueness and consumer ethnocentrism. When these results are examined, a significant difference is observed between age and conscious awareness and consumer ethnocentrism $(p<0.05)$. Tukey test results should be checked to understand from which group the significant discrepancies arise.

Table 7: Tukey Test Results Regarding Age and Conscious Awareness

\begin{tabular}{|l|l|l|l|}
\hline \multicolumn{5}{|l|}{ Conscious Awareness } \\
\hline Tukey HSD a,b & & Subset for alpha $=0.05$ \\
\cline { 3 - 5 } Age & $\mathrm{N}$ & 1 & 2 \\
\hline $18-25$ & 178 & 39.5730 & 41.7077 \\
\hline $26-35$ & 130 & 41.7077 & 44.2813 \\
\hline 46 and above & 32 & 44.2813 & 45.0741 \\
\hline $36-45$ & 61 & & 0.366 \\
\hline Sig. & & 0.106 & . \\
\hline
\end{tabular}

The conscious awareness level of consumers in the 36-45 age group is higher than those in the other age group.

Table 8: Tukey Test Result on Age and Consumer Ethnocentrism

\begin{tabular}{|l|l|l|l|}
\hline \multicolumn{5}{|l|}{ Consumer ethnocentrism } \\
\hline Tukey HSD \\
\hline \multirow{2}{*}{ Age } & \multirow{2}{l}{ S,b } & Subset for alpha $=0.05$ & \\
\cline { 3 - 5 } & $\mathrm{N}$ & 1 & 2 \\
\hline $36-45$ & 81 & 51.6914 & 55.9385 \\
\hline $26-35$ & 130 & 55.9385 & 57.3750 \\
\hline 46 and above & 32 & 57.3750 & 60.9831 \\
\hline $18-25$ & 178 & & 0.202 \\
\hline Sig. & & 0.120 & 2 \\
\hline
\end{tabular}

Consumers in the 18-25 age group have higher perceptions of ethnocentrism than consumers in the other age group.

Table 9. ANOVA Results on Education of Consumers and Conscious Awareness, Consumer Uniqueness and Consumer Ethnocentrism

\begin{tabular}{|c|c|c|c|c|}
\hline Variable & Education & $\begin{array}{l}\text { Mean } \\
(\overline{\mathbf{X}})\end{array}$ & F Value & Sig. (p) \\
\hline Conscious Awareness & $\begin{array}{l}\text { High School } \\
\text { Associate degree } \\
\text { Bachelor's Degree } \\
\text { Postgraduate }\end{array}$ & $\begin{array}{l}45.1667 \\
34.7426 \\
41.8023 \\
47.1447 \\
\end{array}$ & 19.564 & 0.000 \\
\hline Consumer uniqueness & $\begin{array}{l}\text { High School } \\
\text { Associate degree } \\
\text { Bachelor's Degree } \\
\text { Postgraduate }\end{array}$ & $\begin{array}{l}37.444 \\
32.6337 \\
31.8663 \\
33.1579 \\
\end{array}$ & 4.515 & 0.004 \\
\hline Consumer ethnocentrism & $\begin{array}{l}\text { High School } \\
\text { Associate degree } \\
\text { Bachelor's Degree } \\
\text { Postgraduate }\end{array}$ & $\begin{array}{l}62.7426 \\
53.9826 \\
52.6842 \\
57.3634 \\
\end{array}$ & 13.045 & 0.000 \\
\hline
\end{tabular}

Table 9 shows the results of ANOVA regarding the education of consumers, conscious awareness, consumer uniqueness and consumer ethnocentrism. When these results are examined, a significant difference is observed between age and all variables $(p<0.05)$. Tukey test results should be checked to understand from which group the significant discrepancies arise. 
E. Özkan Pir 13/1 (2021) 375-393

Table 10: Tukey Test Results Regarding Education and Conscious Awareness

\begin{tabular}{|l|l|l|l|l|}
\hline \multicolumn{2}{|l|}{ Conscious Awareness } & \\
\hline \multicolumn{3}{|l|}{ Tukey HSD ${ }^{\mathrm{a}, \mathrm{b}}$} & \multirow{2}{|l|}{ Subset for alpha =0.05 } & \\
\hline \multirow{2}{*}{ Education } & $\mathrm{N}$ & 1 & 2 & 3 \\
\hline Associate degree & 101 & 34.7426 & & \\
\hline Bachelor's Degree & 172 & & 41.8023 & \\
\hline High School & 72 & & 45.1667 & 45.1667 \\
\hline Postgraduate & 76 & & & 47.1447 \\
\hline Sig. & & 1.000 & 0.201 & 0.654 \\
\hline
\end{tabular}

The education group with the highest conscious awareness is graduate, while the group with the lowest conscious awareness is those who have received an associate degree.

Table 11: Tukey Test Result Regarding Education and Consumer Uniqueness

\begin{tabular}{|c|c|c|c|}
\hline \multicolumn{4}{|c|}{ Consumer uniqueness } \\
\hline \multicolumn{4}{|l|}{ Tukey HSD } \\
\hline \multirow[b]{2}{*}{ Education } & \multirow[b]{2}{*}{$\mathrm{N}$} & \multicolumn{2}{|c|}{ Subset for alpha $=0.05$} \\
\hline & & 1 & 2 \\
\hline Bachelor's Degree & 172 & 31.8663 & \\
\hline Associate degree & 101 & 32.6337 & \\
\hline Postgraduate & 76 & 33.1579 & \\
\hline High School & 72 & & 37.4444 \\
\hline Sig. & & 0.853 & 1.000 \\
\hline
\end{tabular}

The education group with the highest consumer uniqueness is those with high school education. The education group with the lowest consumer uniqueness is those with undergraduate education.

Table 12: Tukey Test Results for Education and Consumer Ethnocentrism

\begin{tabular}{|c|c|c|c|}
\hline Consumer ethnoce & & & \\
\hline Tukey HSD & & & \\
\hline & & Subset for a & \\
\hline Education & $\mathrm{N}$ & 1 & 2 \\
\hline Postgraduate & 76 & 52.6842 & \\
\hline Bachelor's Degree & 172 & 53.9826 & \\
\hline Associate degree & 101 & & 62.7426 \\
\hline high school & 72 & & 62.8333 \\
\hline Sig. & & 0.933 & 1.000 \\
\hline
\end{tabular}

While the perception of consumer ethnocentrism is highest among those who have an undergraduate and high school education, the perception of consumer ethnocentrism is lowest among those who have received undergraduate and graduate education. As education increases, consumer ethnocentrism decreases. 
E. Özkan Pir 13/1 (2021) 375-393

Table 13. ANOVA Results on Consumers' Income and Conscious Awareness, Consumer Uniqueness and Consumer Ethnocentrism

\begin{tabular}{|c|c|c|c|c|}
\hline Variable & Education & $\begin{array}{l}\text { Mean } \\
\text { (X) }\end{array}$ & F Value & Sig. (p) \\
\hline Conscious Awareness & $\begin{array}{l}\text { Have no regular income } \\
\text { Less than } 2500 \mathrm{TL} \\
2501-5000 \\
5001-7000 \\
7501 \mathrm{TL} \text { and above }\end{array}$ & $\begin{array}{l}40.8721 \\
38.5949 \\
41.7305 \\
42.2394 \\
47.4318\end{array}$ & 3.796 & 0.005 \\
\hline Consumer uniqueness & $\begin{array}{l}\text { Have no regular income } \\
\text { Less than } 2500 \mathrm{TL} \\
2501-5000 \\
5001-7000 \\
7501 \mathrm{TL} \text { and above }\end{array}$ & $\begin{array}{l}31.1279 \\
38.8101 \\
33.8101 \\
29.7324 \\
31.8636 \\
\end{array}$ & 8.226 & 0.000 \\
\hline Consumer ethnocentrism & $\begin{array}{l}\text { Have no regular income } \\
\text { Less than } 2500 \mathrm{TL} \\
2501-5000 \\
5001-7000 \\
7501 \mathrm{TL} \text { and above }\end{array}$ & $\begin{array}{l}62.9070 \\
61.4177 \\
57.5532 \\
49.6761 \\
51.0455 \\
\end{array}$ & 11.241 & 0.000 \\
\hline
\end{tabular}

Table 13 shows the results of ANOVA regarding incomes of consumers, conscious awareness, consumer uniqueness and consumer ethnocentrism. When these results are examined, there is a significant difference between income and all variables $(\mathrm{p}<0.05)$. Tukey test results should be checked to understand from which group the significant discrepancies arise.

Table 14: Tukey Test Results Regarding Age and Conscious Awareness

\begin{tabular}{|l|l|l|l|}
\hline Conscious Awareness \\
\hline \multirow{2}{*}{ Tukey HSD ${ }^{\mathrm{a}, \mathrm{b}}$} & \multirow{3}{|l|}{ Subset for alpha $=0.05$} \\
\hline & $\mathrm{N}$ & 1 & 2 \\
\hline Income & 79 & 38.5949 & \\
\hline Less than 2500 TL & 86 & 40.8721 & \\
\hline No regular income & 141 & 41.7305 & \\
\hline $2501-5000$ & 71 & 42.2394 & 42.2394 \\
\hline $5001-7500$ & 44 & & 47.4318 \\
\hline More than 7501 & & 0.376 & 0.079 \\
\hline Sig. & &
\end{tabular}

While the income group with the highest conscious awareness is those who earn more than $7500 \mathrm{TL}$, the income group with the lowest conscious awareness is those with an income of less than $2500 \mathrm{TL}$.

Table 15: Tukey Test Result Regarding Income and Consumer Uniqueness

\begin{tabular}{|l|l|l|l|}
\hline \multicolumn{4}{|l|}{ Consumer uniqueness } \\
\hline Tukey HSD ${ }^{\mathrm{a}, \mathrm{b}}$ & \multirow{3}{|l|}{ Subset for alpha $=0.05$} \\
\hline & $\mathrm{N}$ & 1 & 2 \\
\hline Income & 71 & 29.7324 & \\
\hline $5001-7500$ & 86 & 31.1279 & \\
\hline No regular income & 44 & 31.8636 & \\
\hline More than 7501 & 141 & 33.5957 & \\
\hline $2501-5000$ & 79 & & 38.8101 \\
\hline Less than 2500 TL & & 0.192 & 1.000 \\
\hline Sig. & & & \\
\hline
\end{tabular}


The income group with the highest consumer uniqueness is those with an income of less than $2500 \mathrm{TL}$. The income group with the least consumer uniqueness is those with an income of 5001-7500 TL.

Table 16: Tukey Test Result Regarding Income and Consumer Ethnocentrism

\begin{tabular}{|l|l|l|l|l|}
\hline \multicolumn{2}{|l|}{ Consumer ethnocentrism } & \\
\hline \multirow{2}{*}{ Tukey HSDa,b } & \multirow{2}{*}{ Subset for alpha $=0.05$} & \\
\cline { 3 - 6 } Income & $\mathrm{N}$ & 1 & 2 & 3 \\
\hline $5001-7500$ & 71 & 49.6761 & & \\
\hline More than 7501 & 44 & 51.0455 & 51.0455 & \\
\hline 2501-5000 & 141 & & 57.5532 & 57.5532 \\
\hline Less than 2500 TL & 79 & & & 61.4177 \\
\hline No regular income & 86 & & & 62.9070 \\
\hline Sig. & & 0.981 & 0.063 & 0.187 \\
\hline
\end{tabular}

While the income group with the highest consumer ethnocentrism is those who do not have a regular income, the income group with the lowest consumer ethnocentrism is those between 5001-7000 TL.

\section{Conclusion}

For businesses that want to better analyze their consumers in their target markets and meet their demands and needs, it is very important to know the reasons for their behaviour. Therefore, it is necessary to analyze the factors affecting consumer behaviour. Consumers may have to choose between domestic and foreign products due to factors such as price, quality, brand, fashion, country of origin and consumer ethnocentrism. Knowing which of these factors is the result of this choice is important for marketing strategies to be developed. Consumer ethnocentrism ceases to be a disadvantage for foreign companies, and can become an advantage that will bring success for domestic companies, when taken carefully. In this context, marketing strategies and promotion efforts gain importance.

According to the research results, the conscious awareness perceptions of the consumers do not have any effect on consumer ethnocentrism. However, consumer uniqueness has a positive impact on consumer ethnocentrism. Besides, conscious awareness of male consumers is higher than female consumers. Single individuals have higher consumer uniqueness and consumer ethnocentrism than married consumers. The conscious awareness level of consumers in the 36-45 age group is higher than those in the other age group. Consumers in the 18-25 age group have higher perceptions of ethnocentrism than consumers in different age group. The education group with the highest conscious awareness is graduate, while the group with the lowest conscious awareness is those who have received an associate degree; the education group with the highest consumer uniqueness is those with high school education. The education group with the lowest consumer uniqueness is those with undergraduate education. While the perception of the consumer, ethnocentrism is the highest among those who have graduate and high school education, the perception of consumer ethnocentrism is the lowest among those who have received undergraduate and postgraduate education. As education increases, consumer ethnocentrism decreases. While the income group with the highest conscious awareness is those with an income of more than $7500 \mathrm{TL}$, the income group with the lowest conscious awareness is those with an income of less than $2500 \mathrm{TL}$; The income group with the highest consumer uniqueness is those with an income of less than $2500 \mathrm{TL}$. The income group with the least consumer uniqueness is those with an income of 5001-7500 TL; While the income group with the highest consumer ethnocentrism is those without a regular income, the income group with the lowest consumer ethnocentrism is between 5001-7000 TL.

The acceptance-rejection of the research hypotheses are as follows: H1, H3b, H3c, H4a, H5b are rejected, H2, H3a, H4b, H4c, H5a, H5c, H6a, H6b, H6c, H7a, H7b, H7c are accepted.

Having a high level of Conscious Awareness allows good mental and physical health and interpersonal relationships (Azak, 2018). Conscious awareness, which includes not delaying the pleasure of life, is being able to remain calm when faced with any problem. Individuals who have acquired conscious awareness live in 
harmony with their past. These individuals, who specialize in being positive in all areas of life, solve their problems by focusing on the causes of the distress, not on the distress they face. In the study, the fact that the conscious awareness level of the consumers in the 36-45 age group is higher than the consumers in the other age group shows that the conscious awareness level of the people increases with experience. The fact that the income group with the highest conscious awareness earns more than $7500 \mathrm{TL}$, while the lowest conscious awareness is those with an income of less than 2500 TL may indicate that the economic level and independence of the consumers can move away from life chaos and financial difficulties and make more accurate consumption decisions.

While consumers in developing countries are more interested in imported goods, they ignore their suitability for Consumer Ethnocentrism. The trend of ethnocentric consumption is higher in developed countries in terms of economy and industry. However, interest in imported products in developing countries with developing economies and industries in terms of Consumer Ethnocentrism can be considered benign. The reason for this is that as the economy and industry improve, the ethnocentric trend gets more potent, and the ethnocentric consumer model becomes more evident (Shankarmahesh, 2006: 151).

In their research to measure the ethnocentric tendency levels of American consumers and Russian consumers, they found that female consumers have higher ethnocentric tendency levels than male consumers (Nielsen and Spence, 1997). Isaac and Anwar (2018) stated in their study that gender does not affect the degree of ethnocentrism when men and women are observed. In the study, it was discovered that the consumer ethnocentrism of singles was higher than married consumers, although gender did not affect ethnocentrism.

It has been proven that non-ethnocentric consumers are better educated (Caruana and Magri, 1996). In the study, in parallel with the literature, while the perception of consumer ethnocentrism is highest among those who have received associate and high school education, the perception of consumer ethnocentrism is the lowest in those who have received undergraduate and graduate education. It is observed that as the educational and socio-cultural level increases, the perspective of individuals for imported products changes and their demand increases.As the education level increases, the perception of ethnocentrism decreases; The fact that individuals prioritize the sphericity of the world together with education means that they tend towards common understanding and living conditions besides their own beliefs and cultures.

Consumers with a high need for uniqueness generally adopt new brands sooner than those with low uniqueness. It suggests that such consumers may have a higher intention to change brands or a lower level of brand loyalty. Segmentation of local markets according to the ethnocentric levels of consumers has become an essential strategy for companies. Ethnocentric consumers consider purchasing products of foreign origin as unacceptable behaviour as it will harm the country's economy. According to the results of the research, conscious awareness perceptions do not have any effect on consumer ethnocentrism. Still, consumer uniqueness has a positive impact on consumer ethnocentrism. For all these reasons, it is of great importance to measure the degree of the ethnocentrism tendency of consumers, to examine which factors affect consumers more, and to determine the relationship with variables such as demographic characteristics. Foreign companies who are careful about this issue can avoid the negative effects of consumer ethnocentrism and domestic companies can reach larger markets and sales volumes by taking advantage of this concept. Positioning the origin of the product less visible on the product's label, and marketing it on the internet, where consumers do not pay attention to the origin of the product, are examples of activities that can be done to overcome the negative effects of consumer ethnocentrism. The important point here is that the amount of ethnocentric elements to be included in the messages is well adjusted. Otherwise, this may cause consumers to react to domestic products.

Especially, it is very important to carry out this research on the basis of the product, which is important in terms of finding the real needs and trends of the consumers that make up the target market, such as choosing the target market to be entered, determining which parts of the selected market are more profitable, and developing marketing strategies suitable for the selected target market. Knowing the relationships between product individual values and consumer ethnocentrism will provide important information to know consumer behaviour and firms, in marketing management, in evaluating market opportunities, in knowing which market is more profitable, in analyzing markets. In the future, studies to be carried out on the basis of sector or product will be able to be directed by obtaining more specific and clear results. 


\section{References}

Allen, T. D., and Kiburz, K. M. (2012). Trait mindfulness and work-family balance among working parents: The mediating effects of vitality and sleep quality. Journal of Vocational Behavior, 80(2), 372-379.

Armağan, E.A., and Gürsoy, Ö. (2011). Satın alma kararlarında tüketici etnosentrizmi ve menşe ülke etkisinin CETSCALE ölçeği ile değerlendirilmesi. Organizasyon ve Yönetim Bilimleri Dergisi, 3(2): 67-77.

Asil, H.,and Kaya, İ. (2013). Türk tüketicilerin etnosentrik eğilimlerinin belirlenmesi üzerine bir araştırma. İstanbul Üniversitesi İşletme Fakültesi Dergisi, 42(1): 113-132.

Azak, A. (2018). Hemşirelik öğrencilerinin bilinçli farkındalık düzeylerinin belirlenmesi. Hemşirelikte Eğitim ve Araştırma Dergisi, 15(3), 170-176.

Balabanis, G. and Diamantopoulos, A. (2004). Domestic country bias, country-of-origin effects and consumer ethnocentrism: a multidimensional unfolding approach. Journal of Marine Science, 32(1): 80-95.

Belk, R. (1985). Materialism: Trait aspects of living in the material world. Journal of Consumer Research, 265-280.

Brock, T. (1968). Implications of commodity theory for value change. A. Greenwald, T. Brock, and T. Ostrom, Psychological foundations of attitudes (s. 243275). New York: Academic Press.

Brown, K. W., and Ryan, R. M. (2003). The benefits of being present: mindfulness and its role in psychological well-being. Journal of personality and social psychology, 84(4), 822-848.

Carmody, J., Reed, G., Kristeller, J., and Merriam, P. (2008). Mindfulness, spirituality, and health-related symptoms. Journal of Psychosomatic Research, 64(4), 393- 403.

Caruana A., Magri E. (1996). The Effect of Dogmatism and Social Class Variables on Consumer Ethnocentrism in Malta.Marketing Intelligence and Planning, 14(4), 39-44.

Cassidy, T., and Lynn, R. (1989). A multifactorial approach to achievement motivation: The development of a comprehensive measure. Journal of Occupational Psychology, 301-312.

Cömert, E. (2019). Marka kişiliği ve tüketici etnosentrizmi arasındaki ilişki: hızlı tüketim sektörü üzerine bir araştırma. (Yayınlanmamış Yüksek Lisans Tezi) Marmara Üniversitesi, Sosyal Bilimler Enstitüsü, İstanbul.

Conrad C., Chakrabarty, S., and Brown G.(1997). Social desirability and consumer ethnocentric tendencies. Southwestern marketing association proceedings, March, 182-185.

Crane, R. S., Brewer, J., Feldman, C., Kabat-Zinn, J., Santorelli, S., Williams, J. M. G., and Kuyken, W. (2017). What defines mindfulness-based programs? The warp and the weft. Psychological medicine, 47(6), 990999.

Creswell, J. D., Way, B. M., Eisenberger, N. I., and Lieberman, M. D. (2007). Neural correlates of dispositional mindfulness during affect labeling. Psychosomatic Medicine, 69(6), 560-565.

Cutura, M. (2006). The impacts of ethnocentrism on consumers' evaluation processes and willingness to buy domestic vs. imported goods in the case of Bosnia and Herzegovina. South East European Journal of Economics and Business, 1(2), 54-63

Dane, E., and Brummel, B. J. (2014). Examining workplace mindfulness and its relations to job performance and turnover intention. Human Relations, 67(1), 105-128.

Dutt, C., and Ninov, I. (2016). The role of mindfulness in tourism: Tourism businesses' perceptions of mindfulness in Dubai, UAE. Turizam: međunarodniznanstveno-stručničasopis, 64(1), 81-95.

Eryiğit, C. and Kavak, B. (2011). Moderator roles of interpersonal effects on the influence of consumer ethnocentrism on intention to buy foreign products: a cross cultural testing. Ekonomik ve Sosyal Araştırmalar Dergisi, 7(2): 97-118.

Evanschitzky, H., Wangenheim, F. V. and Woisetschlager, D. (2008).“Consumer Ethnocentrismin the German Market".International Marketing Review, 25(1), 7-32

Falkenström, F. (2010). Studying mindfulness in experienced meditators: A quasi experimental approach. Personality and Individual Differences, 48(3), 305-310. 
Flugel-Colle, K. F., Vincent, A., Cha, S. S., Laura, L. L., Bauer, B.A., and Wahner-Roedler, D. L. (2009). Measurement of quality of life and participant experience with the mindfulness based stres reduction program. Complementary Therapies in Clinical Practice

Fromkin, H. (1970). Effects of experimentally aroused feelings of undistinctiveness upon valuation of scarce and novel experiences. Journal of Personality and Social Psychology, 521-529.

Good, D. J., Lyddy, C. J., Glomb, T. M., Bono, J. E., Brown, K. W., Duffy, M. K. and Lazar, S. W. (2016). Contemplating mindfulness at work: An integrative review. Journal of Management, 42(1), 114-142.

Good, L.K. and Huddleston, P. (1995). Ethnocentrism of Polish and Russian consumers: are feelings and intentions related?.International Marketing Review, 12(5): 35-48.

Granzin, K. L., and Painter, J. J. (2001). Motivational influences on "Buy Domestic" purchasing: Marketing management implications from a study of two nations. Journal of International Marketing, 9(2), 73-96.

Han, C.M. (1990). Testing the Role of Country Image in Consumer Choice Behaviour. European Journal of Marketing, 24(6), 24-40. S

Herche, J. (1992), "A Note on the Predictive Validity of the CETSCALE". Journal of the Academy of Marketing Science, 20 (3), 261-264.

Himp, T.A. and Sharma, S. (1987). Consumer Ethnocentrism: Construction and Validation of the CETSCALE. Journal of Marketing Research, 24(3), 280289.

Hodgins, H. S., and Knee, C. (2002). The integrating self and conscious experience. In E. L. Deci, R. M. Ryan (Eds.), Handbook of self-determination research (pp. 87100). Rochester, NY US: University of Rochester Press.

Isaac C.,and Anwar S.S. (2018). Consumer ethnocentrism, market mavenism and social network analysis. Faculty of Business and Law, School of Marketing, Curtin University, Australia

İşler, D.B. (2013). Tüketici etnosentrizmi ve menşe ülke etkisi ekseninde satın alma kararındaki rolü: CETSCALE ölçeği ile biruygulama. AÏBÜ Sosyal Bilimler Enstitüsü Dergisi. 13(1): 93-121.

Javalgi, R. G., Khare, V. P., Gross, A. C., and Scherer, R. F. (2005). An application of the consumer ethnocentrism model to French consumers. International Business Review, 14(3), 325-344.

Jimenez, N. H. and San Martin, S. (2010). The role of country-of-origin, ethnocentrism and animosity in promoting consumer trust. The moderating role of familiarity, International Business Review, 19 (1): 3445.

Julie, H. Y., and Albaum, G. (2002). Sovereignty change influences on consumer ethnocentrism and product preferences: Hong Kong revisited one year later. Journal of Business Research, 55(11), 891-899.

Kabat-Zinn, J. (2003). Mindfulness based interventions in context: Past, present and future. Clinical Psychology Science Practice, 10: 144-156.

Kabat-Zinn, J., andHanh, T. N. (2009). Full catastrophe living: Using the wisdom of your body and mind to face stress, pain, and illness. Delta Press, Boston.

Kao, D. T. (2013). The İmpacts Of Consumer's Need For Uniqueness (CNFU) And Brand Personality On Brand Switching İntentions. Journal of business theory and practice, 1.1, 83-94.

Kavak, B. and Gümüşlüoğlu, L. (2007). Segmenting food markets the role of ethnocent-rism and lifestyle in understanding purchasing intentions. International Journal of Market Research, 49(1), 71-94.

Kaynak, E. and Kara, A. (2001). An Examination Of The Relationship Among Consumer Lifestyles, Ethnocentrism, Knowledge Structures, Attitudes and Behavioural Tendencies: A Comparative Study In. Two CIS States. International Journal Of Advertising, (20), 455-482.

Kaynak, E., and Kara, A. (2002). Consumer perceptions of foreign products. European Journal of marketing.36 (7-8), 928-949.

Kirkpatrick, K. L. (2005). Enhancing self-compassion using a Gestalt two-chair intervention (Doctoral dissertation). The University of Texas at Austin. Retrieved from ProQuest Dissertations and Theses Full Text

Klein, J. G., Ettenson, R., andMorris, M. D. (1998). The animosity model of foreign product purchase: An empirical test in the people's republic of China. Journal of Marketing, 62(1), 89-100 
Küçük, E. (2019). Bilinçli Farkındalık ve Psikolojik Sermayenin Çalışanların İyi Oluş Hali Üzerindeki Rolü (Master's thesis,). Hacettepe Üniversitesi, Sosyal Bilimler Enstitüsü, Ankara.

Küçükaydın, S. (2012). Tüketici etnosentrizmi ve ülke menşei etkisinin tüketicilerin yabancı markalı ürün tercihi ve satın alma niyeti üzerine etkisi. (Yayınlanmış Doktora Tezi) Marmara Üniversitesi, Sosyal BilimlerEnstitüsü, İstanbul.

Küçükemiroğlu, O. (1999). Market segmentation by using consumer lifestyle dimensions and ethnocentrism. European Journal of Marketing, 33(5/6), 470-487.

Kwak, H., Jaju, A. and Larsen, T. (2006). Consumer ethnocentrism offline and online: the mediating role of marketing efforts and personality traits in the United States, South Korea, and Italy. Journal of Academy of Marketing Science, 34(3): 367- 385.

Lan, Y., Ding, JE.,Li, W., Li, J., Zhang, Y., Liu, M. and Fu, H. (2018). A pilot study of a group mindfulness-based cognitive-behavioral intervention for smartphone addiction among university students. Journal of Behavioral Addictions, 7(4), 1171-1176.

Laurie, J., and Blandford, A. (2016). Making time for mindfulness. International journal of medical informatics, 96, 38-50.

Lykins, E. L., and Baer, R. A. (2009). Psychological functioning in a sample of long-term practitioners of mindfulness meditation. Journal of cognitive Psychotherapy, 23(3), 226-241.

Lynn, M. (1991). Scarcity effects on value: A quantitative review of the commodity theory literature. Psychology and Marketing, 43-57.

Mohamad, O.; Ahmad, Z.U.; Honeycutt, E.D. and Tyebkhan, T.H. (2000). Does 'Made in...' Matter to Consumers? A Malaysian Study of Country of Origin Effect. Multinational Business Review, 8(2), 69-73.

Moore, A., and Malinowski, P. (2009). Meditation, mindfulness and cognitive flexibility. Consciousness and Cognition, 18(1), 176-186.

Nielsen, J. A. and Spence, M. T., (1997). A Test of Stability of The Cetscale, A Mesaure of Comsumer Ethnocentric Tendencies. Journal of Marketing Theory and Practice, 68-76.

Okechuku, C. (1994). The Importance of product COO. European Journal of Marketing. 28(4), 5-19

Okechuku, C. and V. Onyemah. (1999). “Nigerian Consumer Attitudes Toward Foreign and Domestic Products". Journal of International Business Studies, 30(3), 611-622.

Özyeşil, Z., Arslan, C., Kesici, Ş. And Deniz, M.E. (2011). Bilinçli Farkındalık Ölçeği'ni Türkçe'ye uyarlama çalışması. Ĕğitim ve Bilim, 36(160), 224-235.

Papadopoulos, N., Heslop, L.A. and Beracs, J. (1989). National Stereotypes and Product Evaluations in a Socialist Country. International Marketing Review, 7(1), 32-47.

Paşalığlu, H. (2018). Yaşam tarzı, tüketici yenilikçiliği ve tüketici benzersizliğinin elektrikli araçları satın alma niyeti üzerine etkisi. (Yayınlanmamış Yüksek Lisans Tezi), Karabük Üniversitesi, Karabük.

Paşalıŏlu, H., and Cengiz, H. (2019). Tüketici yaşam tarzının elektrikli araçları satın alma niyeti üzerine etkisi: Tüketici yenilikçiliği, tüketici benzersizliği ve keşifsel davranışların aracılık etkisi. International Congress on Business and Marketing. s. 35-45.

Piron, F. (2002).“International Outshopping and Ethnocentrism”. European Journal of Marketing. 36(1/2), 189210.

Rajamma, R. K., Pelton, L. E., Hsu, M. K., and Knight, D. K. (2010). The impact of consumers' need for uniqueness and nationality on generation Y's retail patronage behaviors: Investigating American and Taiwanese consumers. Journal of global marketing, 23(5), 387-410.

Reardon, J., Miller, C., Vida, I., and Kim, I. (2005). The effects of ethnocentrism and economic development on the formation of brand and ad attitudes in transitional economies. European Journal of Marketing.

Reb, J., Narayanan, J., and Chaturvedi, S. (2014). Leading mindfully: Two studies on the influence of supervisor trait mindfulness on employee well-being and performance. Mindfulness, 5(1), 36-45.

Remmers, C., Topolinski, S., and Koole, S. L. (2016). Why being mindful may have more benefits than you realize: Mindfulness improves both explicit and implicit mood regulation. Mindfulness, 7(4), 829-837. 
Roth, M.S. and Romeo, J.M. (1992). Matching product category and country image perceptions: A framework for managing COO effects. Journal of International Business Studies, 3, 477-497.

Rybina, L., Reardon, J. and Humphrey, J. (2010). Patriotism, Cosmopolitanism, Consumer Ethnocentrism and Purchase Behaviour in Kazakhstan. Organizations and Markets in Emerging Economies. 2(2), 92-107.

Schooler, R. (1971). Bias Phenomena Attendant to the Marketing of Foreign Goods in the U.S. Journal of International Business Studies, 2(1), 71-80.

Shankarmahesh, M. (2006). Consumer ethnocentrism: An integrative review of its antecedents and consequences. International Marketing Review, 23(2), 146- 172.

Shapiro, S. L., Brown, K. W., Thoresen, C., and Plante, T. G. (2011). The moderation of mindfulness-based stress reduction effects by trait mindfulness: Results from a randomized controlled trial. Journal of Clinical Psychology, 67(3), 267-277.

Shapiro, S. L., Oman, D., Thoresen, C. E., Plante, T. G., and Flinders, T. (2008). Cultivating mindfulness: Effects on well-being. Journal of Clinical Psychology, 64(7), 840-862.

Sharma, S. And Shimp, T. A., (1987). Consumer Ethnocentrism: Construction and Validation of the CETSCALE. Journal of Marketing Research, Published by American Marketing Association. 24 (3), pp.280-289.

Sharma, S., Shimp, T. A. and Shin, J., (1995). Consumer Ethnocentrism: A Test of Antecedents and Moderators. Journal of the Academy of Marketing Science. 23 (1), 26-37.

Shimp, T. A. (1984). Consumer Ethnocentrism: The Consept and a Preliminary Emprical Test. Advances in Consumer Research, 285-290..

Shonin, E., Van Gordon, W., Dunn, T. J., Singh, N. N., and Griffiths, M. D. (2014). Meditation awareness training (MAT) for work-related wellbeing and job performance: A randomised controlled trial. International. Journal of Mental Health and Addiction, 12(6), 806-823.

Siegel, R. D. (2009). The mindfulness solution: Everyday practices for everyday problems. Guilford Press.

Snyder, C. (1992). Product scarcity by need for uniqueness interaction: A consumer Catch-22 carousel. Basic and Applied Social Psychology, 9-24.

Snyder, C., and Fromkin, H. (1980). Uniqueness: The human pursuit of difference. New York: Plenum Press.

Solomon, R. (2017). Consumer Behaviour; Buying, Having And Being. Harlow: Pearson,

Steele, M. M. (2008). Leading high reliability schools: The effects of organizational mindfulness on collective efficacy. The University of Texas at San Antonio.

Tian, K. T., Bearden, W. O., and Hunter, G. L. (2001). Consumers' need for uniqueness: Scale development and validation. Journal of consumer research, 28(1), 50-66.

Tırışkan, M., Onnar, N., Çetin, Y.A. and Cömert, I.T. (2015). Madde bağımlılı̆̆ında nüksü önlemede bilinçli farkındalığın önemi: birderlemeçalışması. Addicta: The Turkish Journal on Addictions, 2(2), 123-142.

Toksarı M., Senir, G. (2015). Menşe ülke etkisinin satın alma kararındaki etkisi. Uluslararası Sosyal Araştırmalar Dergisi. 40(8): 793-805.

Torlak, Ö.,Özçelik, D.G., (2011). Marka Kişiliği Algısı İle Etnosentrik Eğilimler Arasındaki İlişki: Levis ve Mavi Jeans Üzerine Bir Araştırma. Ege Akademik Bakış Dergisi, 11( 3), 366.

Tuncer M.A., and Gökşen, H. (2016). İçecek sektöründe tüketici etnosentrizmi: Türkiye-Hollanda karşılaştırmalı uygulaması. International Review of Economics and Management, 4(1): 67-95.

Ünal,A. (2019). Bireysel Değerler İle Tüketici Etnosentrizmi Arasındaki İlişkinin İncelenmesi: Dumlupınar Üniversitesi Öğrencileri Üzerinde Araştırma. (Yayınlanmamış Yüksek Lisans Tezi) Kütahya Dumlupınar Üniversitesi, Sosyal BilimlerEnstitüsü, Kütahya.

Upadhyay, Y. and Singh, S.K. (2006). Preference for Domestic Goods: A Study of Consumer Ethnocentrism. The Journal of Business Perspective, 10(3), 59-68.

Uyar K., Dursun, Y. (2015). Farklı ürün kategorilerinde yabancı markalama ve tüketici etnosentrizmi. Atatürk Üniversitesi Sosyal Bilimler Ens. Dergisi, 19(2): 363-382. 
Uzkurt, C. and Özmen, M. (2004). Tüketici Etnosentrizmi ve Ülke Orijini Etkisinin TüketicilerinYerli ve Yabancı Ürünlere Yönelik Tutumlarına Etkileri. 9. Ulusal Pazarlama Kongresi, 6-8 Ekim, Ankara: Gazi Üniversitesi, 262-274.

Van Gordon, W., Shonin, E., Zangeneh, M., and Griffiths, M. D. (2014). Work-related mental health and job performance: Can mindfulness help?. International Journal of Mental Health and Addiction, 12(2), 129-137.

Varma, P. (1998). The Middle Comes First It Happens Hota Hai, The Great Indian Middle Class, Outlook India. (http://www.outlookindia.com/full.asp?fodname=20071112 andfname $=$ APawan + Varma $+\% 28 \%$ 29andsid $=1$ ).

Vassella, M.C., Fountain, P.D., ve Fountain, U.K. (2010). Consumer ethnocentrism, patriotism global openness and country of origin effect: A literatüre review. ASBBS Annual Conference: Las Vegas, 17(1), 868-882

Vida, I. and Fairhurst, A. (1999). Factors underlying the phenomenon of consumer ethnocentricity: evidence from four central European countries. The International Review of Retail, Distribution and Consumer Research, 9(4): 321-337

Wang, C-K. (1978). The Effect of Foreign Economic, Political and Cultural Environment and Consumers' SocioDemographics on Consumers' Willingness to Buy Foreign Products. Doktora Tezi, Graduate College of Texas A and M University.

Weinstein, N., Brown, K. W., and Ryan, R. M. (2009). A multi-method examination of the effects of mindfulness on stress attribution, coping, and emotional wellbeing. Journal of research in personality, 43(3), 374-385.

Witkowski, T.H. 1998. Consumer ethnocentrism in two emerging markets: determinants and predictive validity. Advances in Consumer Research, 25(1): 258-63

Yapraklı, T.Ş. andKeser, E. 2013. Tüketici etnosentrizmi: beyaz eşya ve içecek sektörlerinde karşılaştırmalı bir saha araştırması, Selçuk Üniversitesi İktisadi ve İdari Bilimler Fakültesi Sosyal ve Ekonomik Araştırmalar Dergisi, 2013: 25.

Yıkılmaz, M. and Demir Güdül, M. (2015). Üniversite öğrencilerinde yaşamda anlam, bilinçli farkındalık, algılanan sosyoekonomik düzey ve yaşam doyumu arasındaki ilişkiler. Ege Eğitim Dergisi, 16(2), 297315.

Yousıf, M. N.B.(2019). Tüketici Etnosentrizmi Ve Menşe Ülke Etkisinin Algılanan Marka Değeri Ve Satın Alma Niyeti Üzerindeki Etkisi: Türkiye Ve Sudan Karşılaştırması (Yayınlanmamış Yüksek Lisans Tezi) Kocaeli Üniversitesi, Sosyal Bilimler Enstitüsü, Kocaeli. 